\title{
Rakúska škola a výzvy 21. storočia
}

\section{Austrian school and challenges of the 21st century}

\section{Mária Horehájová, Jana Marasová}

Abstract: The aim of the paper is to present the economic theory of the Austrian school as a current concept of thought, offering starting points for post-crisis and post-pandemic changes in the economy and society. The authors first describe the essential ideas of the Austrian school, which differs from the mainstream economics. It is associated with business activity based on the free decisions of economic agents in the market, which is the essence of economic interactions and processes. Subsequently, the authors briefly compare the relationship between the state and the market from the perspective of the Austrian school on the one hand and especially the Keynesian branch of the mainstream economics on the other hand, particularly in the period after World War II. At the same time, they emphasize the importance of interdisciplinary cooperation with other social sciences and humanities in the necessary changes in post-pandemic economic and social development. Finally, the paper outlines the priorities of given changes, which include in particular the areas of education, science and research, and the reform of the legal system.

Key words: Economics. Austrian schoo. Liberal approach. Post-pandemic development.

JEL Classification: B13, B53.

\section{Úvod}

Krízové obdobia spravidla motivujú $\mathrm{k}$ väčšej aktivite pri hl'adaní riešení rôznych spoločenských a ekonomických problémov, ktoré kríza priniesla, resp. vyostrila. Najväčší povojnový prepad ekonomiky v rokoch 2008 a nasledujúcich, t. j. v období finančnej, hospodárskej a dlhovej krízy, znásobil úsilie hl’adania riešení a zmierňovaní jej dôsledkov. O desat'ročie neskôr spoločnost' a ekonomika musia čelit' dopadom pandémie COVID-19, teda d’alšej kríze, ale s odlišným charakterom. Ekonomika nenarazila na „bubliny“ vyrastajúce z jej 
fungovania: práce i kapitálu je $\mathrm{v}$ nej dostatok, len sa vplyvom mocenských zásahov zdôvodňovaných potrebou protipandemických opatrení obmedzila možnost' ich využívania.

Pri riešení problémov sa používali štandardné či neštandardné nástroje hospodárskej politiky teoreticky vymedzované poznatkami mainstreamovej ekonómie, ale skúmali sa aj poznatky alternatívnych koncepcií, objasňujúce rozsiahlu ekonomickú problematiku z iného uhla pohl'adu. Hospodárska činnost' má svoje teoretické jadro v poznaní mainstreamovej ekonómie, ale rozsah, zložitost' a komplexnost' problematiky vytvárala vel'ký priestor aj pre iné vysvetlenia a koncepcie. Dôsledky tejto teórie a z nej vyplývajúcej hospodárskej politiky za ostatné desat'ročia otvorili väčší priestor úvahám o širšom využití poznatkov rakúskej školy.

\section{Podstata rakúskej ekonómie}

Vznik a počiatočné formovanie rakúskej školy ekonómie spadajú do obdobia konca 19. storočia. Od jeho 70. rokov prebiehala tzv. marginálna revolúcia, ktorá kvalitatívne menila obsah a zameranie ekonómie a jej skúmania. V troch navzájom nezávislých školách sa postupne sformovali tri odlišné podoby vysvetl'ovania marginálneho princípu ako východiska skúmania ekonomických procesov a javov. Predstavitelia lausannskej školy (L. Walras, 2014; V. Pareto, 2014) sa svojou teóriou všeobecnej ekonomickej rovnováhy pokúšali vyjadrit’ podmienky, za ktorých možno dosiahnut' rovnováhu v celom národnom hospodárstve. Cambridgeská škola (A. Marshall, 2013), analyzujúc podmienky čiastkovej ekonomickej rovnováhy na trhu jedného statku, sformovala v zásade dnešnú podobu štandardnej mikroekonómie. Obe školy pritom v rozsiahlej miere využívali matematiku. Spolu vytvorili neoklasickú ekonómiu.

Rakúska škola (C. Menger, 2019; F. Wieser, 2010; E. Böhm-Bawerk, 1991), označovaná aj ako psychologická, rozvinula chápanie marginálneho princípu v podobe teórie hraničnej užitočnosti s dvoma základnými prvkami - užitočnost'ou a vzácnost'ou statku na jednej strane a subjektívnou teóriou hodnoty na druhej strane. Odlišný uhol pohl'adu predstavitel'ov tejto školy nevyžadoval matematiku a spočiatku sa chápal ako vhodný doplnok k neoklasickej ekonómii. Od začiatku 20. storočia sa začali prejavovat' d’alšie odlišnosti, ktoré postupne viedli $\mathrm{k}$ oddeleniu oboch teórií $\mathrm{v} 30$. rokoch 20 . storočia.

Vtedy sa na ekonomickej scéne objavujú nové myšlienky, ovplyvnené najmä dôsledkami Vel'kej hospodárskej krízy (1929 - 1933) a najpregnantnejšie formulované britským ekonómom J. M. Keynesom (2017). Jeho prístup z pozície metodologického kolektivizmu, konštatovanie straty samoregulačnej schopnosti trhu a nutnosti štátnych intervencií do hospodárskych procesov, akceptovali postupne aj predstavitelia neoklasickej teórie. V takejto 
inovovanej podobe, obohatená o makroekonómiu, sa neoklasická ekonómia stala hlavným prúdom ekonomickej teórie v povojnovom období - mainstreamom.

Jadrom skúmania mainstreamu sa stalo hl'adanie rovnováhy, pričom sa v rastúcej miere využívali kvantitatívne nástroje a modelovanie podmienok a vývoja ekonomiky pre jej dosiahnutie. Tento prístup sa akceptuje ako objektívny jednak preto, lebo rovnováha vyjadruje, že všetko čo sa vyrobilo, sa aj predalo a spotrebovalo, teda zdroje sa využili najefektívnejšie, čo je pre ekonomiku rozhodujúce. Zároveň je rovnováha princíp často spájaný s harmóniou, ktorú sa l'udia snažia dosiahnut' v najrôznejších oblastiach a ktorá je synonymom správnosti, resp. optimálnosti, v ekonomike často spätej s požiadavkami maximalizácie. Súlad spoločnosti s prírodou je aktuálnym príkladom volania po harmónii a rovnováhe, ktorú súčasné fungovanie ekonomiky čoraz viac narúša. Narúšanie rovnováhy sa väčšinou chápe ako nežiadúce, preto vyvoláva požiadavku jej znovu nastolenia a to nielen v ekonomickej, ale aj v iných oblastiach. Analýza rovnováhy na všetkých úrovniach ekonomiky je preto legitímnym objektom ekonomického skúmania a po kríze v 30. rokoch a negatívnych dôsledkoch druhej svetovej vojny sa zdalo prirodzené zabránit' takémuto vývoju do budúcnosti. Preto sa neoklasická ekonómia stala jadrom mainstreamu hl'adajúceho rovnováhu na všetkých trhoch a v celej ekonomike, pričom odsunula rakúsku školu medzi alternatívne, teda druhoradé teórie, nehodiace sa do obdobia povojnovej ekonomiky v druhej polovici 20. storočia.

Neoklasická škola zároveň akceptovala niektoré myšlienky socialistických teórií, ktorých vplyv rástol od prvej polovice 20. storočia, pričom od jeho 20. rokov k tomu prispievala aj komparácia týchto teórií $\mathrm{s}$ reálnou praxou budovania centrálne plánovanej ekonomiky $\mathrm{v}$ bývalom ZSSR a po druhej svetovej vojne i v d’alších krajinách strednej a východnej Európy.

Skúmanie rovnováhy však nie je jediným spôsobom chápania ekonomickej problematiky, čo vysvetl'uje aj prístup rakúskej školy. Pôvod odlišností rakúskej a neoklasickej ekonómie možno hl'adat' v rozdieloch metodologických prístupov. Metodologický individualizmus bol pôvodne spoločný pre obe teórie, ale rakúska škola od začiatku zdôrazňovala zásadne nový prístup - subjektivizmus. Jeho podstatou bola myšlienka, že ekonomika je vždy postavená na človeku ako hlavnej postave všetkých sociálnych procesov, čo umožnilo novú formuláciu teórie spontánneho vzniku a evolúcie všetkých spoločenských inštitúcií, chápaných ako určité vzorce správania. Inštitúcie sú výsledkom sociálnych procesov tvorených obrovským počtom l’udských činov, ktoré reprezentujú postupné učenie sa prostredníctvom pokusov a omylov. Výsledkom je nové správanie a konanie, najefektívnejšie na danej úrovni, odrážajúce l'udské interakcie a formujúce adekvátne spoločenské inštitúcie. 
Na týchto poznatkoch sa, hlavne v dielach L. v. Misesa (2006) a F. A. Hayeka (1995), rozvinula jedna z t’ažiskových myšlienok rakúskej ekonómie, že spoločenské inštitúcie sú nezamýšl’anými spoločenskými dôsledkami individuálnych činov. Tieto individuálne činy môžu byt' v danom čase a konkrétnom priestore viac-menej rozumné, ale individuálny rozum by sotva vedel a priori naprojektovat' tieto inštitúcie, teda vziat' do úvahy obrovské množstvo rozptýlených dynamických informácií, ktoré sa spájajú len cez interakcie l’udí. V hospodárstve sa táto koordinácia deje najmä prostredníctvom inštitúcie trhu. (Soto, 2012; Boettke, 2011; Mises, 2006).

Rakúska škola vychádza zo subjektivizmu, teda z reálneho konania skutočných l’udí, ktoré má byt' východiskom pre formulovanie teórie. Objektivizmus neoklasikov vychádza z rozhodovania založeného na očakávaných nákladoch a výnosoch, a má viest’ k efektívnej alokácii zdrojov. V zásade sa však neoklasici snažia spätne racionalizovat' všetky minulé rozhodnutia na základe analýzy nákladov a výnosov v rámci matematickej maximalizácie.

Oproti neoklasickému homo oeconomicus Rakúšania vyzdvihujú podnikatel'a, ktorého hlavnou úlohou je tvorit' a objavovat' nové dovtedy neexistujúce informácie, umožňujúce konkrétnu činnost' a subjektívne konanie. Pokial' tieto informácie nie sú známe, nemožno ani vopred robit' žiadne neoklasické alokačné rozhodovanie založené na očakávaných nákladoch a výnosoch. Subjektívne chápanie informácie patrí k základným prvkom rakúskej metodológie na rozdiel od neoklasického objektívneho chápania, $v$ ktorom je informácia prvkom kupovaným a predávaným ako každý iný tovar na trhu, na základe maximalizačných rozhodnutí.

Práve z dôrazu na podnikanie ako hybnej sily ekonomiky (Kirzner, 1998; Mises, 2006; Horeháj, Šuplata, 2020) rakúska škola vyvodzuje požiadavku skúmania ekonómie ako priestoru trvalej nerovnováhy odporujúcej neoklasickým predstavám o rovnovážnosti. Trhová ekonomika, vzt’ahy dopytu a ponuky majú síce tendenciu k rovnováhe, ktorú však sotva môžu dosiahnut' z dôvodu dynamiky a nepretržitosti ekonomických procesov podnikania. V rámci nich, ked' podnikatel' objaví príležitost' a využije ju, spúšt'a spontánny proces koordinácie sociálnych procesov predstavujúcich tendenciu k rovnováhe.

Pri skúmaní rovnovážnych stavov je možný aj matematický formalizmus, ktorý neoklasická ekonómia vo vel'kej miere uplatňuje. Tento formalizmus však pri analýze neumožňuje využívat' subjektívnu časovost' a už vôbec nie podnikatel'skú tvorivost', ktoré sú podstatnými prvkami rakúskeho analytického diskurzu. Neoklasický statický prístup tak nie je abstraktno-teoretickým odrazom dynamickej ekonomickej praxe, skôr len akýmsi „,zastaveným obrázkom nepretržitého filmu ekonomiky“،, ktorý nám vo svojej statickej a zjednodušenej 
podobe ukazuje podstatu ekonomických procesov. Inak povedané, rakúska škola preto nepovažuje používanie matematiky za potrebné, lebo matematická metóda spája veličiny, ktoré sú heterogénne z hl'adiska času a podnikatel'skej tvorivosti.

Z uvedeného potom logicky vyplýva, že empirická verifikácia je v ekonómii nemožná, pretože vedecký „pozorovatel““ nemôže mat’ subjektívnu informáciu, ktorú „pozorovaní“ podnikatelia neustále vytvárajú a objavujú prostredníctvom decentralizovaného procesu. Tieto poznatky vedú aj k odmietaniu myšlienky, že ekonómia by mala predpovedat’ budúci vývoj, čo naopak, neoklasici široko akceptujú a snažia sa o to na základe konštrukcie rovnovážnych modelov. Paradoxne, tieto predpovede sa zväčša nepotvrdzujú, naopak, boli to predstavitelia rakúskej školy, ktorí na základe svojej koncepcie hospodárskych kríz predvídali napríklad vznik Vel'kej hospodárskej krízy v 30. rokoch 20. storočia, krízu v rokoch 2008 - 2009 či rozpad socialistického systému centrálne plánovaného hospodárstva.

Rakúska škola demonštruje, že ekonomickú teóriu možno logicky rozvíjat' pri zahrnutí kategórií času a tvorivosti, teda bez potreby používat' funkcie či predpoklady konštantnosti, ktoré sa nezlučujú s tvorivou povahou l'udí ako jediných protagonistov sociálnych procesov.

Vyššie uvedené rozdiely a ani celý rad d’alších odlišností neznamenajú, že celá neoklasická teória je, z rakúskeho pohl'adu, chybná. Naopak, väčšinu z nej možno akceptovat'. Rakúšania chcú len ukázat', že platnost' neoklasických záverov sa nedá garantovat’ a že dynamická analýza poskytuje istejší a plodnejší spôsob, ako dospiet' k platným záverom (Jonáš a kol., 1994).

\section{Materiál a metódy skúmania}

Analýza súčasnej pandémie ako jednej z výziev 21. storočia nie je v kompetencii ekonómie. Jej dôsledky na hospodárstvo spolu so zásadnými technologickými zmenami v podobe digitalizácie ekonomiky, procesov globalizácie, migrácie či ekologických vplyvov však spolu formujú čoraz silnejšiu požiadavku zásadných ekonomických a spoločenských zmien v období po prekonaní pandémie. Aj prostriedky Európskej únie vyčlenené vo výške 750 mld. EUR na nadchádzajúcich sedem rokov majú slúžit' obnove ekonomiky, ale nie v predpandemickej podobe. Majú pomôct' sformovat' nový digitálno-ekologický spôsob hospodárenia, ktorého centrom by mal byt' človek, jeho tvorivé schopnosti a aktívna činnost'.

Pri hl'adaní konkrétnej podoby novej ekonomiky je teoretickým východiskom nielen štandardná (mainstreamová) ekonómia, ale i existujúce alternatívne teórie, ba vznikajú nové predstavy, názory a koncepcie špeciálne zamerané na túto problematiku. Vychádzajúc z poznania a chápania tak hospodárskeho systému ako aj rakúskej školy predpokladáme, že táto škola vytvára dostatočný priestor pre žiadúce zmeny v post-pandemickom vývoji. Ciel’om 
nášho príspevku je na jednej strane priblíženie niektorých podstatných stránok rakúskej školy ako alternatívnej teórie, ktoré môžu mat' užšiu súvislost' s riešením vyššie nastolených problémov. Na druhej strane chceme načrtnút' a vyzdvihnút' niektoré prvky požadovaných zmien, ktoré adekvátnejšie reflektuje práve rakúska škola.

Teória rakúskej školy a jej doterajšie poznatky sú východiskovým materiálom a sekundárnym zdrojom, ktorý pri spracovaní tejto problematiky využívame. $Z$ toho logicky vyplýva, že metodologickým východiskom nášho prístupu je individualizmus ako protiklad kolektivizmu najmä keynesovskej vetvy hlavného prúdu ekonómie, ktorý sa dnes vníma ako jadro ekonomickej teórie väčšinou ekonómov. V rozsahu nevyhnutnom pre potreby tohto príspevku používame aj čiastočnú komparáciu oboch prístupov s ciel’om poukázat’ na možnosti, ktorými môže rakúska škola prispiet’ k formovaniu post-pandemickej podoby ekonomiky.

\section{Výsledky a diskusia}

Vymedzenie podstaty rakúskej školy v prvej časti - ako spontánne vzniknutého a vyvíjajúceho sa ekonomického systému založeného na podnikatel’skej aktivite a tvorivosti, ako i liberálnom chápaní fungovania spoločenských inštitúcií (slobodného trhu, súkromného vlastníctva a rešpektovania dohôd) - dopíňame $\mathrm{v}$ tejto časti jej stručnou komparáciou $\mathrm{s}$ prevažujúcou mainstreamovou (štandardnou) teóriou a praxou.

\subsection{Rakúska škola, trh a štát}

Akceptovanie niektorých prvkov štandardnej ekonómie rakúskou školou sa len minimálne týka makroekonomickej problematiky. Ked’že ekonomika je to, čo konajú, resp. realizujú hospodárske subjekty, predstavitelia rakúskej školy chápu makroekonómiu len ako súhrn štatistických údajov. Vzt’ah ekonomiky a politiky vnímajú tiež odlišne.

Hoci „zmiešaný“ charakter povojnovej ekonomiky a rast vplyvu štátu v nej, opierajúci sa o rozvoj keynesovskych teórií, sa postupne stal ekonomickým štandardom i spoločenskou normou, známa fráza „dnes sme všetci keynesovci“ (Buchholz, 1990, s. 217), nebola celkom pravdivá. Išlo skôr o presadzovanie politického želania, ktoré malo potvrdzovat' „prirodzenost““ trvalej prítomnosti štátu v ekonomike a potrebu rastúceho byrokratického aparátu.

Dôsledkom takéhoto vývoja a chápania fungovania ekonomického systému boli viaceré problémy povojnového hospodárstva. Štátne intervencie na jednej strane zrejme prispeli k dočasnému zmierneniu cyklických výkyvov, najmä v 50. a 60. rokoch v porovnaní s predvojnovým vývojom, a spolu s dovtedy nevídaným vedecko-technickým pokrokom ako aj prostredníctvom rozsiahlych prerozdel'ovacích procesov prispeli k výraznému zvýšeniu 
spotreby a životnej úrovne širokých vrstiev obyvatel'stva (štát blahobytu). Na druhej strane, rast štátnych intervencií a aktivít štátu spomalili štrukturálne zmeny ekonomiky, čím obmedzili možnosti jej rýchlejšieho vývoja. V 70. rokoch rastúci intervencionizmus vyústil do stagflácie ekonomiky, ktorú keynesovska hospodárska politika už nedokázala svojimi nástrojmi regulovat'. Riešením bola zmena hospodárskej politiky na neokonzervatívnu, ktorá obmedzila intervencie a štátne regulácie a dala dôraz na trhový mechanizmus, využívajúc predovšetkým nepriame nástroje monetárnej politiky.

Vznik a uplatňovanie neokonzervatívnej hospodárskej politiky ovplyvnili najmä neokonzervatívne teórie - monetarizmus, teória racionálnych očakávaní, ekonómia strany ponuky či teória verejnej vol'by, pre ktoré bolo inšpiráciou aj ocenenie predstavitel'a rakúskej školy F. A. Hayeka Nobelovou cenou v roku 1974. Hoci sa rakúska škola a monetarizmus M. Friedmana v niektorých dôležitých otázkach nezhodujú, ich spoločný dôraz na obmedzovanie pôsobenia štátu $\mathrm{v}$ ekonomike i v spoločnosti vôbec, ako aj preferovanie trhovej regulácie $\mathrm{v}$ hospodárskej politike a praxi, podporili ich teoretické presvedčenie o životaschopnosti trhu a jeho vyššej efektívnosti v porovnaní so štátom. Práve táto hospodárska politika umožnila rýchlejší rozvoj a aplikáciu moderných technológií, ktorých vplyv sa stal dominantným v d’alšom vývoji v 21. storočí.

Napriek historickým skúsenostiam s pozitívnym vplyvom slobodného trhu aj v povojnovej ekonomike, ku ktorým patrí tzv. ordoliberálna hospodárska politika L. Erharda v západnom Nemecku vedúca k „nemeckému hospodárskemu zázraku“, či riešenie spomenutej stagflácie v 70. rokoch, myšlienka trhových zlyhaní a nutnosti štátnych intervencií sa v ekonomickom a zrejme ani spoločenskom diskurze už nespochybňuje. Stalo sa prirodzeným, že ked' trh zlyháva, je povinnost'ou štátu tieto zlyhania naprávat'. Žial', s rovnakou samozrejmost'ou sa nehl'adí na zlyhania štátu, ktoré môžu byt' ovel'a škodlivejšie pre ekonomiku i celú spoločnost', a to najmä z dlhodobého hl'adiska. Práve rakúska škola zdôrazňuje, že v skutočnosti majú zlyhania štátu väčší negatívny dopad na hospodársku činnost’ než trhové zlyhania.

Kritika zo strany liberálov sa však často odmieta na základe vlastnej predstavy napr. predstavitel'ov decíznej sféry o liberálnom učení rakúskej školy, ktoré interpretujú vo vel'mi zjednodušenej, tendenčnej až karikatúrnej podobe. Následne ho vyvracajú plytkými argumentami, deklaráciami či duchaplnost’ami a svoje názory široko popularizujú prostredníctvom politicko-mediálnej sféry (Boettke, 2011; Hayek, 1995).

Ekonómovia rakúskej školy sa snažia dlhodobo a vytrvalo konfrontovat' podstatu fungovania trhu, a to aj v komparácii s keynesovstvom, štátnymi intervenciami, ich prejavmi a dôsledkami. Postupný príklon k intervencionizmu vo všeobecnosti sa pokúšajú vysvetlit' 
pomocou viacerých prvkov vo vývoji modernej priemyselnej ekonomiky. V tejto súvislosti je predovšetkým potrebné uviest' myšlienky kolektivizmu (holizmu), ktoré sa začali rozširovat' v dobe osvietenstva v 18. storočí, narastali s požiadavkami sociálnej spravodlivosti v zmysle materiálnej rovnosti v 19. storočí, a vyvrcholili v 20. storočí, kedy Keynesovo učenie zmenilo metodologický individualizmus dovtedajšieho vývoja ekonomickej teórie na metodologický kolektivizmus ako základ d'alšieho ekonomického skúmania.

Metodologický kolektivizmus sa stal prít’ažlivým okrem iného aj tým, že umožnil preniest' individuálnu zodpovednost' na kolektívnu, t. j. kolektivizovat' individuálne straty a získavat' tak aj mimo vlastných nákladov z kolektívnych zdrojov. Kolektivizmus podporovala tiež viera $\mathrm{v}$ moderné vedecko-technické poznatky, najmä v organizačno-riadiacej oblasti, umožňujúce zlepšit' regulačné procesy. Podobne v tomto smere pôsobili negatívne dôsledky krízových javov, vojen a snaha vyhnút' sa v budúcnosti ich opakovaniu.

Na druhej strane, podl'a rakúskej školy, ani postupnou demokratizáciou nestratila politika svoju mocenskú povahu. Nedobrovol'ný charakter mocenských vzt'ahov, v porovnaní s dobrovol'nými vzt'ahmi v iných spoločenských oblastiach vrátane hospodárskej, je zretel'ne menej efektívny. Pritom možnost' mocenského rozhodovania vytvára trvalý priestor pre zneužívanie moci, odrážajúce sa v zlyhaniach štátu. Stopercentnú ochranu pred zneužívaním moci, korupciou či klientelizmom nedokáže zabezpečit' ani štruktúra mocenských inštitúcií sformovaných do podoby vzájomnej kontroly v demokratických krajinách, o nedemokratických štátoch ani nehovoriac. Dokonca ani predpoklad len „dobrých úmyslov“ politikov či štátnych úradníkov nezaručuje kompetentné a správne rozhodnutia. Predstavitelia štátnych inštitúcií totiž vždy rozhodujú o cudzích prostriedkoch na rozdiel od trhových subjektov, ktoré využívajú vlastné prostriedky pre vlastnú činnost', na vlastnú zodpovednost', teda podliehajú bezprostrednej trhovej regulácii, a tým aj rizikám z nej vyplývajúcim.

Krízy a vojnové konflikty sú dôsledkom primárne mocenského rozhodovania. Trhové procesy uskutočňované na základe miliónov každodenných rozhodnutí a následného konania a interakcií hospodárskych subjektov samozrejme nevylučujú individuálne chybné rozhodnutia. $\mathrm{V}$ mierových podmienkach však nemôže systém skolabovat' ako celok z podstaty svojho fungovania, nepretržitých evolučných zmien a priebežných korekcií dopytom a ponukou. Vznik kríz a vel'kých nerovnováh $v$ trhovej, resp. zmiešanej ekonomike je preto dôsledkom skôr zlyhania štátu než zlyhania trhu.

Negatívny vplyv štátu v hospodárstve sa naplno prejavil najmä v centrálne regulovanej socialistickej ekonomike, ktorej nemožnost' dlhodobého fungovania teoreticky objasnil popredný predstavitel' rakúskej školy v 20. storočí, L. von Mises už v roku 1920 v diele 
Ekonomická kalkulácia v socialistickom spoločenstve. Analýzou dospel k záveru, že bez slobodného trhu a trhových cien nie je možná žiadna racionálna ekonomická kalkulácia. Túto rakúsku „dogmu“ prakticky dokumentoval a potvrdil rozpad centrálne regulovaného systému na prelome 80. a 90. rokov minulého storočia v krajinách strednej a východnej Európy.

Osobitne je treba uviest' problematiku finančnej sféry, ktorej rakúska ekonómia venuje väčšiu pozornost'. Finančná sféra je prierezovou, teda prepája všetky sektory ekonomiky a odráža aj ekonomicko-politickú dichotómiu. Hoci sa peniaze historicky vyvinuli z výmeny ako špecifický tovar $\mathrm{s}$ adekvátnou, teda plnou hodnotou, vývoj vedúci $\mathrm{k}$ používaniu neplnohodnotných peňazí, ktorých hodnotu garantuje mocenská inštitúcia - štát, je empirickým príkladom vplyvu mocenských nástrojov, ich využívania i zneužívania.

Sformovanie súčasného finančného systému, od zlatého štandardu 19. storočia, cez obmedzený dolárový štandard bretton-woodskeho menového systému po druhej svetovej vojne až po dnešný systém centralizovanej meny, vrátane medzinárodnej - Euro, centrálnej banky a centrálneho regulovania monetárnou politikou, to všetko výrazne zdeformovalo pôvodnú trhovú podstatu finančnej sféry, ktorá má dnes v zásade socialistický charakter. V tejto podobe má podporovat' makroekonomické ukazovatele, hlavne poskytovat' dostatok prostriedkov na podporu ekonomického rastu, zamestnanosti, či cenovej stability formou tzv. cielenej inflácie. Týmito ukazovatel'mi prezentujú politici svoj úspech, pokial' sú čísla kladné. Ak sú hodnoty a ich vývoj nepriaznivé, je to podl'a nich spravidla dôsledok trhových zlyhaní. Vzhl’adom na skutočný podiel a úlohu trhu a štátu vo finančnom sektore je slovné spojenie ,zlyhanie finančného trhu“ viac než zvláštne.

Práve v tomto sektore hl'adali príčinu cyklického vývoja ekonomiky predstavitelia rakúskej školy, najmä F. A. Hayek (In G. Dostaler, 2001), ktorý spomenutú Nobelovu cenu dostal za príspevok $\mathrm{k}$ peňažnej teórii priemyselného cyklu. Pochopitel'ne, Nobelova cena nie je verifikáciou pravdy v ekonómii (Jonáš a kol., 1994). Podstatou nerovnováhy, resp. krízy je podl'a Hayeka úverová expanzia, ktorou sa štát snaží maximalizovat' produkciu, dosiahnut' maximálny či „udržatel'ný“ rast, pričom monetárnou politikou zvyšuje dostupnost' a ponuku finančných prostriedkov. Dochádza k investičnému boomu, ale kvôli prevahe prostriedkov v nevhodnej odvetvovej štruktúre - odvetvia „vyšších rádov“, teda najvzdialenejšie od spotreby - sú potrebné obrovské objemy dodatočných prostriedkov na dokončenie investícií, ktoré však už systém nedokáže generovat', a tak dochádza k nerovnováhe.

$\mathrm{Na}$ základe vývoja od začiatku 21. storočia a poznatkov o úverovej expanzii patrili predstavitelia rakúskej školy k tým ekonómom, ktorí dokázali predvídat’aj vznik krízy v roku 2008, v ktorej expandovali predovšetkým finančné deriváty. 
Napriek empirickým faktom a snahe liberálnych ekonómov, etatistická paradigma prevažuje v teórii i praxi hospodárskej politiky vyspelých krajín. Snaha rýchlejšie dosiahnut' želané výsledky je plne v duchu Keynesovho bonmotu „V dlhom období sme všetci mítvi“ (Keynes, 1924, s. 80). „Výhody“ kolektivizmu a možnost' rýchlejšieho dosiahnutia výsledkov pomocou mocenských nástrojov sú príliš lákavé, najmä (ale nielen) pre tých, ktorí môžu bezprostredne profitovat' z politických rozhodnutí.

Menej sa berú do úvahy dlhodobé dôsledky takéhoto politického rozhodovania, ktoré v budúcnosti vedie k novým sociálno-ekonomickým problémom. Základné trhovo-ekonomické zákonitosti však nad’alej platia, hoci sú prekrývané stále väčším politickým balastom, ako to dokazuje liberálna ekonómia, najmä rakúska škola, vytrvalo žiadajúca obmedzovanie štátnych intervencií a regulácií, dnes aj vzhl’adom na potrebu zásadných ekonomických a spoločenských zmien v post-pandemickej budúcnosti (Caldwell, 2005; Karpiš, 2015; Soto, 2009).

\subsection{Rakúska škola a možnosti zmien}

Učenie rakúskej školy je $\mathrm{v}$ súčasných podmienkach intenzívnejšieho hladania novej podoby rozvoja ekonomiky a spoločnosti stále aktuálnym a jeho akceptovanie by umožnilo formovanie adekvátnejšieho systému oproti doterajšiemu. Nielen využitím poznatkov ekonomického obsahu tohto učenia, ale aj snahou širšie prepájat' rôzne spoločenské oblasti, najmä prostredníctvom ústrednej postavy sociálnych procesov - človeka ako hospodárskeho subjektu.

Rakúska škola je teória, ktorá k hlbšiemu pochopeniu ekonomickej problematiky využíva vo väčšom rozsahu poznatky iných spoločenských vied, resp. vidí užšie spojitosti s inými spoločenskými oblast’ami. Už pôvodné označenie rakúska „psychologická“ škola avizovalo nutnost' skúmania subjektívnych motivácií, dnes sčasti rozvíjané napr. v behaviorálnej ekonómii (Serra, 2017; Thaler, 2019 a d’alší). Misesova praxeológia vyjadrovala axiómy platné pre akékol'vek l'udské konanie a Hayekova práca od vydania Cesty do nevol'níctva (1944) výrazne presahovala problematiku „čistej ekonómie“. Treba však podotknút', že prienik ekonómie do iných oblastí $\mathrm{v}$ epoche rastu kolektivizmu, etatizmu a intervencionizmu nenachádzal vždy priaznivú odozvu $\mathrm{v}$ iných sociálnych disciplínach, resp. spoločenské a humanitné vedy vo väčšej miere akceptovali kolektivistickú podobu ekonómie ako „humánnejšiu“".

Prezentácia súčasných krízových problémov spojených $\mathrm{s}$ pandémiou, ako výzvy $\mathrm{k}$ zásadným zmenám, je z pohl’adu rakúskej školy apelom pre celé spektrum nielen prírodnotechnických, ale aj humanitno-sociálnych vied. Digitalizácia ekonomiky, problematika 
životného prostredia, klimatických zmien, ako i demografického vývoja a migračných tendencií, dnes čoraz užšie súvisia s potrebou a požiadavkami novej kvality „l'udského kapitálu“, t. j. človeka-tvorcu, a predstavujú obrovskú výzvu prakticky pre všetky odbory. Prenechat' pritom príliš vel'ký priestor mocenskej praxi, teda hospodárskej politike a iným politikám, politikom a byrokracii, je z pohl'adu liberálnej ekonómie a na pozadí negatívnych dôsledkov doterajšieho intervencionizmu - vid’ aktuálne napr. fungovanie štátnych inštitúcií a konanie ich predstavitel'ov pri riešení pandémie - príliš vel'kým rizikom.

Rakúska škola chápe vývoj ako trvalý a nepretržitý, prinášajúci aj nečakané zmeny, ktoré treba priebežne, adaptačne riešit'. Vždy to posúva na vyššiu úroveň aj potrebu adekvátnych znalostí, vedomostí, poznania. Dnešná požiadavka zásadných zmien vyžaduje zodpovedne konajúci subjekt, uvedomujúci si podstatu i potrebu zmien, čo je sotva možné bez adekvátneho prispenia spoločenských vied, vrátane ekonómie.

Preto prvým objektom ich spoločného záujmu v nasledujúcom období by mal byt' vzdelávací systém a nevyhnutné zmeny spojené so vzdelávacou a vedecko-výskumnou činnost'ou. Osobitne je to dôležité v podmienkach Slovenska, kde dlhodobý finančný deficit viedol k devastácii týchto oblastí na úroveň menej vyspelých rozvojových krajín. Odmietanie rozsiahleho štátu v intenciách rakúskej školy má v našej krajine zvlášt’ naliehavé opodstatnenie, ked'že v priebehu troch desat'ročí sa zatial' nenašla politická garnitúra, ktorá by skutočne chápala úlohu a význam školstva, vedy a výskumu pre modernú ekonomiku a spoločnost', a ktorá by postupne reálne zvyšovala nevyhnutné množstvo prostriedkov pre dané oblasti. Aktuálne znižovanie finančných prostriedkov do tohto sektora nemožno ospravedlnit' ani pandémiou. Jeho dlhodobá politická devastácia je výzvou nielen pre ekonómiu, ale prakticky pre všetky vedné odbory. Preto treba hl'adat' možnosti, ako v tejto oblasti reálne obmedzit' vplyv politiky, ktorá bola doteraz skôr „bojiskom politických záujmov a hier“, v dôsledku čoho je málo pravdepodobné, že by sa povaha takejto politiky v blízkej budúcnosti zmenila.

Možno pritom diskutovat' i o hl'adaní iného modelu financovania tohto dôležitého sektora, ktorý by výrazne obmedzoval politický vplyv a úlohu štátneho rozpočtu - napr. v podobe osobitného fondu vytvoreného vo výške daného percenta $\mathrm{z}$ hrubého domáceho produktu, $\mathrm{s}$ jasnými dlhodobými pravidlami jeho rozdel'ovania podl'a vedecky zdôvodnených princípov.

Popri primárnom dôraze na oblasti l'udského poznania a kreativity - vzdelanie, vedu, výskum, kultúru, ktoré by mali byt' východiskom zmien, je dôležité aj inštitucionálne nastavenie, pri ktorom rakúska škola vyzdvihuje inštitúcie trhu, súkromného vlastníctva a dodržiavanie dohôd, ktoré by mali fungovat' $\mathrm{v}$ ich prirodzenej a čo najmenej štátom deformovanej podobe. 
Súbežne preto treba posilňovat' trhové prostredie, rešpektovanie ekonomických zákonov, vyžadujúce si adekvátne fungovanie právneho systému. Najjednoduchšia charakteristika právneho štátu spočívajúca $\mathrm{v}$ princípe, že platí zákon a platí pre každého, patrí k dôležitým zásadám rakúskej školy. Predpandemické fungovanie právneho systému, vo vel'kej miere ovplyvňované rozsiahlou inerciou bývalého režimu, vyžaduje osobitne dôležitú pozornost'.

V d'alších oblastiach by sa zmeny mali diat' súbežne, resp. nadväzne, a mali by byt' sprevádzané širokou diskusiou o ich prioritách z hl'adiska využívania domácich i európskych fondov vyčlenených na obnovu. Vo všeobecnosti by zmeny mali mat' v zásade evolučný charakter. Možnost' ich urýchlenia politickými rozhodnutiami by sa mala zvažovat' len zriedkavo a opatrne. V ekonomickej, resp. sociálno-ekonomickej sfére by vytváranie väčšieho priestoru pre pôsobenie trhu vplývalo na spoločensko-ekonomický vývoj z dlhodobého hl'adiska stabilizačne.

V intenciách rakúskej školy je pritom dôležitým osvojovanie si a presadzovanie myšlienok o úlohe podnikania a podnikatel'stva „kritickým“ množstvom hospodárskych subjektov, l'udí, prostredníctvom konania ktorých by sa vývoj posúval žiadúcim smerom. Hl'adanie odpovede na otázku, ako rozšírit' prirodzenú snahu podnikat', najmä v krajinách strednej a východnej Európy po desat'ročiach centrálneho plánovania, predstavuje priestor pre širšie skúmanie, nielen ekonomické. Podnikanie totiž okrem osobnosti človeka odráža aj jeho vnímanie sveta, a preto vyžaduje jeho všestrannú kultiváciu.

Pre nevyhnutné zmeny $\mathrm{v}$ individuálnom i globálnom meradle sú potrebné efekty vyplývajúce z poznatkov a skúmania humanitných a spoločenských vied, ktoré nemôžu byt' len „nadstavbou“, akýmsi kultúrnym príveskom, či eticko-estetickým „ornamentom“ spoločnosti, ale primárnym prvkom formujúcim človeka - hlavný ciel' i prostriedok zmien. Stále totiž platí, že charakter spoločnosti je určovaný charakterom jej členov. Jednoducho povedané, v prostredí vzdelaných občanov a rastúcej kvality ich dobrovol’ných interakcií sa vytvára väčšia šanca pre lepšie fungovanie celej spoločnosti.

Reálne evolučné zmeny môžu dosiahnut' len l’udia svojím konaním v konkrétnom čase a priestore, v adekvátnych kauzálnych súvislostiach v smere napĺnania istých ciel’ov, ktoré sú však formulované v zásade len všeobecne, resp. rámcovo. Časté volanie po dlhodobej vízii rozvoja s rozsiahlymi podrobnost'ami neberie do úvahy, že napriek akýmkol'vek snahám budúcnost' pre nás zostáva neznáma, neistá a čím je vzdialenejšia, tým menej je predvídatel'ná. Vývoj nie je lineárny ani pravidelný a len v procese hl’adania riešení najrôznejších problémov možno kreovat' informácie, poznatky, znalosti či vedomosti objavujúce a posúvajúce vývoj spoločnosti d'alej. 
Pochopitel'ne, isté ciele a cesty $\mathrm{k}$ nim sa dajú v hrubých črtách naznačit', napríklad v ekologickej oblasti, pri riešení sociálnych otázok, demografickom vývoji a pod. s tým, že sa budú prioritne kreovat', rozširovat' a realizovat' vedecké poznatky o fungovaní spoločnosti, a nie projekty politických a utopických predstáv, nerešpektujúce zákonitosti evolučného vývoja (Ferguson, 2016; Hayek, 1995; Sowell, 2019).

Rozsiahlost' problematiky prevyšuje rozsah tohto príspevku, v ktorom sme chceli naznačit' aktuálnost' využitia myšlienok rakúskej školy, často pokladaných za zastarané a nevhodné pre podmienky 21. storočia. Sme presvedčené, že ich aplikácia v dnešných podmienkach, založená na ich skutočnom poznaní, môže zásadne prispiet' $\mathrm{k}$ riešeniu vážnych spoločenskoekonomických otázok a k uskutočneniu potrebných adekvátnych spoločenských zmien.

\section{Záver}

Dynamický podnikatel'ský proces je podstatou neustáleho spoločenského napredovania, napomáha tvorbe nových ciel'ov a znalostí šíriacich sa vo vlnách celou spoločnost’ou. Využívanie individuálnych poznatkov a zručností predstavuje súčasne koordináciu spoločenských interakcií. Slobodný trh umožňuje ich najefektívnejšie využitie a prináša prospech všetkým aktívne konajúcim subjektom pri využívaní ich znalostí. Koncept podnikania má l'udskú povahu, čím „robí ekonómiu takou, ako je chápaná a rozvíjaná rakúskou školou, základnou humanitnou vedou“ (Soto, 2012, s. 30). Pre efektívne pôsobenie na realizáciu nevyhnutných zmien vo fungovaní hospodárskeho i spoločenského systému však ekonómia potrebuje vedomostný kapitál iných humanitných vied, aby mohla komplexnejšie skúmat' správanie a rozhodovanie človeka.

Citátom filozofa J. Pavlíka možno na záver zdôraznit’ formovanie fungujúcej občianskej spoločnosti spojené s odmietaním rozsiahlych štátnych intervencií, a to nielen v ekonomike. Podl'a neho: „,... l’udská dejinnost' sa nemusí nevyhnutne realizovat' v politicko-štátotvorných aktivitách ... sféra individuálnych hodnotových orientácií (zahŕňajúca aj štátom nesprostredkovaný a $\mathrm{v}$ politike sa neprejavujúci vzt’ah indivídua $\mathrm{k}$ náboženskému či estetickému absolútnu) poskytuje dostatočný priestor pre post-politickú podobu l'udských dejinných aktivít“" (Pavlík, 2004, s. 804).

Grantová podpora: Finančná podpora z Agentúry na podporu výskumu a vývoja (APVV) grant č. APVV-18-0122 „Postavenie sociálnych a humanitných vied v spoločnosti: ich možnosti a limity“. 


\section{Zoznam použitej literatúry}

[1] Boetke, P. (2011). Robustní politická ekonomie pro 21. století. Praha, CZ: Wolters Kluwer, CEVRO Institut.

[2] Böhm-Bawerk, E. (1991). Základy teorie hospodářske hodnoty statků. Praha, CZ: Academia.

[3] Buchholz, T. G. (1990). Živé myšlenky mrtvých ekonomů. Praha, CZ: Victoria Publishing.

[4] Caldwell, B. (2005). Hayek's Challenge. An Intellectual Biography of F. A. Hayek [Hayekova výzva. Intelektuálna biografia F. A. Hayeka]. Chicago, IL : The University of Chicago Press.

[5] Dostaler, G. (2001). La genèse et l'évolution de la théorie des cycles de Hayek [Genéza a vývoj Hayekovej teórie cyklu]. L'Actualité économique, 77(2), 207-230.

[6] Ferguson, N. (2016). Vel'ký rozklad. O úpadku institucí a zániku ekonomik. Praha, CZ: Argo.

[7] Hayek, F. A. (1995). Osudná domýšlivost. Omyly socializmu. Praha, CZ: SLON.

[8] Horeháj, J., Šuplata, M. (2020). Podnikanie a znalostná ekonomika v intenciách rakúskej školy. Ekonomika a spoločnost', 21(1), 78-86.

[9] Jonáś, J. a kol. (1994). Oslava ekonomie. Praha, CZ: Academia.

[10] Karpiš, J. (2015). Zlé peniaze. Bratislava, SK: INESS.

[11] Keynes, J. M. (2017). Théorie générale de l'emploi, de l'intérêt et de la monnaie [V̌̌eobecná teória zamestnanosti, úrokov a peňazí]. Paris, FR: Payot \& Rivages.

[12] Keynes, J. M. (1924). Atract on monetary reform [Dohoda o menovej reforme]. London, UK: MacMillan and Co.

[13] Kirzner, I. (1998). Jak fungují trhy. Praha, CZ: Liberální institut.

[14] Marshall, A. (2013). Principles of Economics [Princípy ekonómie]. London, UK: Palgrave Macmillan.

[15] Menger, C. (2019). Principles of Economics [Princípy ekonómie]. Auburn, AL: Ludwig von Mises Institute.

[16] Mises, L. v. (2006). Lidské jednání. Pojednání o ekonomii. Praha, CZ: Liberální institut.

[17] Pareto, V. (2014). Manuel d'économie politique [Manuel d'économie politique]. Paris, FR: Hachette Livre BNF.

[18]Pavlík, J. (2004). F. A. Hayek a teorie spontánniho řádu. Praha, CZ: Professional Publishing. 
[19] Serra, D. (2017). Economie comportementale [Behaviorálna ekonómia]. Paris, FR: Economica.

[20] Soto, J. H. (2009). Penize, banky a hospodářske krize. Praha, CZ: ASPI, Liberální institut.

[21] Soto, J. H. (2012). Rakouská škola. Tržni řád a podnikatelská tvořivost. Praha, CZ: Dokořán, CEVRO Institut.

[22] Sowell, T. (2019). Discrimination and Disparities [Diskriminácia a rozdiely]. New York, NY: Hachette Book Group.

[23] Thaler, R. (2019). Misbehaving. La découverte de l'économie comportementale [Neslušné správanie: Objav behaviorálnej ekonómie]. Paris, FR: Seuil.

[24] Walras, L. (2014). Elements of Theoretical Economics [Základy teoretickej ekonómie]. Cambridge, UK: Cambridge University Press.

[25] Wieser, F. (2010). Social Economics [Sociálna ekonómia]. London, UK: Taylor \& Francis Ltd.

Adresa autorov: Mária Horehájová, Jana Marasová, Ekonomická fakulta UMB, Tajovského 10, 97590 Banská Bystrica, e-mail: maria.horehajova@umb.sk; jana.marasova@umb.sk 